------Jou. Raf. Sci., Vol. 20, No.4 pp 1- 10, 2009-----

\title{
Genetic Effects for Yield and some of its Components in Upland Cotton
}

\author{
Khalid M. Dawod \\ Department of Field Crops \\ College of Agric. and Forestry \\ Mosul University
}

\author{
Ghada A. Al-Hamdany \\ Department of Biology \\ College of Science \\ Mosul University
}

(Received 24 / 6 / 2009 ; Accepted 19/ 10 / 2009)

\begin{abstract}
Graphics analysis, components of genetic variation and heritability, for the characters: plant height, number of vegetative branches, number of fruiting branches, number of bolls per plant, boll weight and seed cotton yield, were computed from a half diallel set of seven cotton varieties (Halab90, Sp8886, Delta pine5409, Lachata, Dunn1047, Coker310 and Deer22). The variance due to dominance were generally higher than the additive for all studied characters. Graphics analysis suggested the presence of epistatic gene effects (nonallelic interaction) in high proportion for number of bolls per plant and boll weight, as well as additive gene effect with partial dominance for plant height, number of vegetative branches, number of bolls per plant, and seed cotton yield. Moderate narrow sense heritability was observed in case of plant height whereas low for the remaining characters.

\section{التأثثرات الور اثية للحاصل وبعض مكوناته في القطن الابلند}

الملخص

اعتمدت طريقة تحليل خط الانحدار وتقدير مكونات التباين الوراثي والتوريث الضيق للصفات:

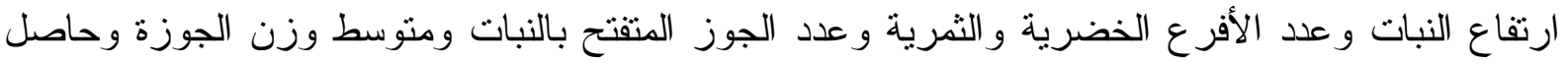

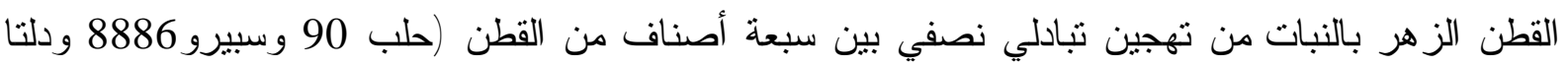
باين5409 و لاثشاتا ودن1047 وكوكر 310 ودير 22). أظهرت النتائج أن مكونات التباين السيادي كانت اكبر

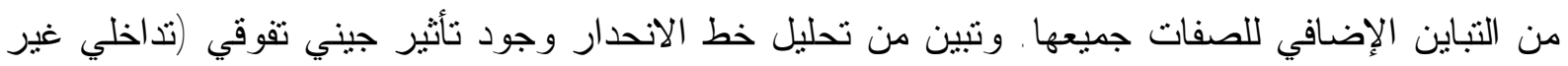

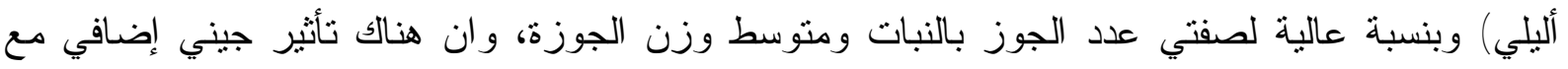

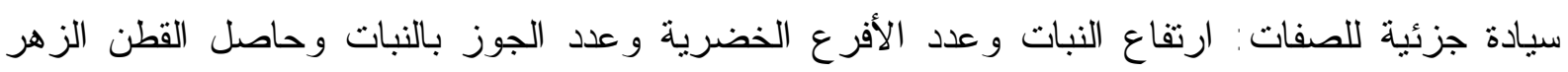

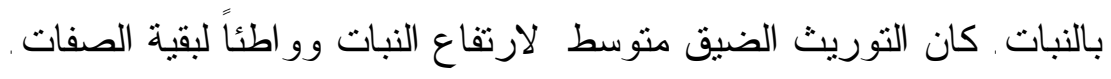




\section{INTRODUCTION}

Improvement in seed cotton yield and other characters of its components has always remained the main objective for the most cotton breeding programmes over all the world. Basic informations concerning with the genetic control of the characters under selection is of quite important when plant breeders are able to apply their programmes efficiently by the choice of appropriate parents and selection methodology.

Moreover, it is highly desirable that the information obtained under the same conditions where selection have to be take place.

Estimation of genetic parameters at several studies, exist concerning the genetic system that control seed cotton yield and its components, some of these estimates are: heritability, gene action involved, potential for improving seed cotton yield and other important characters seems high (Grean and Culp, 1990; Alam et al., 1991; Gomma, 1997; Radi et al., 1999; Ahmad et al., 2005; Murtaza (2005); Ali et al., 2009). Also Jagtab (1986), Jagtab and Kohle (1987), Tomar and Singh (1992), Tariq et al. (1995) and Khan et al. (1999) indicating additive gene effect for seed cotton yield and some of its components, like number of fruiting branches, bolls per plant and boll weight.

Our experiment aims were to obtain more informations about the basis of the genetic variation and to investigate the genetic system nature by Hayman-Jinks model, controlling seed cotton yield and some of its components.

\section{MATERIALS AND METHODS}

The parental cotton varieties used in this study were: (1) Halab90, (2) SP8886, (3) Deltapine5409, (4) Lachata, (5) Dunn1047, (6) Coker310 and (7) Deer22. Hereafter, entries will be identified by number 1 to 7 , as indicated, their $F_{1}$ hybrids will be designated by appropriate number combinations. All possible crosses (excluding reciprocals) were made among these seven varieties. These varieties and their $\mathrm{F}_{1}$ were grown in the field at AlHaweja (Kirkuk Governorate) at 2006 using Randomized Complete Block Design with three replications. Each plot had three rows $5 \mathrm{~m}$ long. The rows were spaced at $75 \mathrm{~cm}$. and plants at $25 \mathrm{~cm}$. within rows. Recommended cultural practices were followed during the crop season. Observations were recorded for six characters, namely, plant height in $\mathrm{cm}$, number of vegetative branches, number of flowering branches, number of bolls per plant, boll weight (calculated as the average weight of seed cotton per boll in gram) and seed cotton yield per plant in gram.

Data analysis was conducted according to the method described by Gomez and Gomez (1983), and the mode of inheritance was determined on the basis of genetic components obtained from $F_{1}$ (Mather and Jinks, 1977, 1982) and variance and covariance graph fabricated using simple additive-dominance model of Hayman (1954a and 1954b) and Jinks (1954). Narrow sense heritability was estimated according to Mather and Jinks (1977, 1982).

\section{RESULTS AND DISCUSSION}

The array means $(\mathrm{X})$, variance $(\mathrm{Vr})$ and covariance $(\mathrm{Wr})$ for the six seed cotton yield and some of its components from seven varieties are presented in table 1 . The variance analysis (Table 2) showed highly significant differences between 28 entries for all six studied characters (plant height, number of vegetative branches, number of fruiting 
branches, number of bolls per plant, boll weight and seed cotton yield per plant), making assurance that the different parents chosen in the present investigation were genetically diversed for all characters under consideration.

Diallel cross analysis based on the following assumptions: (i) diploid segregation (ii) no reciprocal differences (iii) no epistasis (iv) no multiple alleles (v) homozygosity of the parents and (vi) genes independently distributed among parents. Gossypium hirsutum L. which is an amphidiploids behaves almost like a perfect diploid.

Table 1: Means $(\mathrm{X})$ variance $(\mathrm{Vr})$ and covariance $(\mathrm{Wr})$ of seven cotton cultivars

\begin{tabular}{|c|c|c|c|c|c|c|c|c|c|c|}
\hline \multirow{2}{*}{ Cultivars } & \multicolumn{3}{|c|}{ Plant height } & \multicolumn{4}{|c|}{ no. Vegetative branches } & \multicolumn{3}{|c|}{ no. Fruiting branches } \\
\hline & $\mathrm{X}$ & $\mathrm{Vr}$ & $\mathrm{Wr}$ & X & $\mathrm{Vr}$ & $\mathrm{Wr}$ & & X & $\mathrm{Vr}$ & $\mathrm{Wr}$ \\
\hline Halab1 & 53.13 & 1173.5 & 245.1 & 2.600 & 0.352 & -0.0 & & 8.066 & 5.549 & 0.048 \\
\hline Sp8886 & 76.67 & 101.9 & -54.9 & 2.933 & 0.299 & 0.14 & & 8.666 & 1.323 & -0.171 \\
\hline Delta pine & 91.60 & 929.9 & -221.7 & 2.133 & 0.493 & 0.19 & & 8.866 & 6.177 & -1.427 \\
\hline Lachata & 79.53 & 497.3 & 201.7 & 2.333 & 0.321 & 0.19 & & 7.133 & 5.973 & 1.512 \\
\hline Dunn1047 & 69.87 & 384.9 & 98.1 & 2.600 & 0.609 & -0.1 & & 8.200 & 1.539 & -0.453 \\
\hline Coker310 & 102.5 & 97.4 & 102.2 & 1.333 & 0.694 & 0.16 & & 10.80 & 2.203 & 0.112 \\
\hline Deer22 & 91.13 & 643.6 & 197.0 & 2.466 & 0.286 & -0.0 & & 8.533 & 5.156 & 0.144 \\
\hline \multirow{2}{*}{ Cultivars } & \multicolumn{3}{|c|}{ no. of bolls } & \multicolumn{4}{|c|}{ Boll weight } & \multicolumn{3}{|c|}{ Seed cotton yield } \\
\hline & $X$ & $\mathrm{Vr}$ & $\mathrm{Wr}$ & $X$ & $\mathrm{Vr}$ & $\mathrm{Wr}$ & & $X$ & $\mathrm{Vr}$ & $\mathrm{Wr}$ \\
\hline Halab1 & 31.80 & 13.71 & 2.899 & 3.790 & 0.229 & 0.141 & & 51 & 735.22 & 267.43 \\
\hline Sp8886 & 35.07 & 6.97 & 2.411 & 4.026 & 0.431 & 0.234 & & 1.40 & 206.57 & 154.26 \\
\hline Delta pine & 33.41 & 48.88 & -9.824 & 4.593 & 0.155 & 0.077 & & 3.38 & 1616.5 & -339.39 \\
\hline Lachata & 28.53 & 33.56 & -1.097 & 4.336 & 0.160 & 0.024 & & 3.67 & 1547.5 & 124.78 \\
\hline Dunn1047 & 28.33 & 14.19 & -1.512 & 5.860 & 0.322 & 0.327 & & 6.29 & 492.96 & 65.14 \\
\hline Coker310 & 29.73 & 17.62 & -6.284 & 4.910 & 0.232 & 0.034 & & 6.16 & 573.83 & -68.32 \\
\hline Deer22 & 28.80 & 51.15 & -1.644 & 4.423 & 0.179 & 0.127 & & 7.45 & 2146.3 & 337.54 \\
\hline
\end{tabular}

Table 2: ANOVA for yield and it's components in a 7x7 diallel set in cotton.

\begin{tabular}{|c|c|c|c|c|c|c|c|}
\hline Sources & df & $\begin{array}{c}\text { Plant } \\
\text { Height }\end{array}$ & $\begin{array}{c}\text { No. } \\
\text { Vegetative } \\
\text { Branches }\end{array}$ & $\begin{array}{c}\text { No. } \\
\text { Fruiting } \\
\text { Branches }\end{array}$ & $\begin{array}{c}\text { No. of } \\
\text { Bolls }\end{array}$ & $\begin{array}{c}\text { Boll } \\
\text { Weight }\end{array}$ & $\begin{array}{c}\text { Seed Cotton } \\
\text { Yield }\end{array}$ \\
\hline Block & 2 & 3.137 & 0.031 & 0.194 & 5.109 & 0.094 & 418.7 \\
\hline Entries & 27 & $1779.5 * *$ & $1.176^{* *}$ & $11.241^{* *}$ & $71.12^{* *}$ & $0.655^{* *}$ & $2797.8^{* *}$ \\
\hline Error & 54 & 19.943 & 0.049 & 0.345 & 1.963 & 0.120 & 161.12 \\
\hline
\end{tabular}

** Significant at $1 \%$ level.

Reciprocal differences regarding the characters studied in the present investigation have not been reported. The varieties included in the present study were homozygous as they were being maintained by selfing. Likewise the assumptions i, ii and v are satisfied. For testing the other assumptions Hayman (1954) proposed certain test. this test of variance analysis of $\mathrm{Wr}-\mathrm{Vr}$ was applied in present case and it was found that the variance was not significant for all seven studied characters. This indicated that the differences $\mathrm{Wr}-\mathrm{Vr}$ were 
homogenous and the assumptions were fulfilled. The data for the six characters were analyzed for genetic components of variation in terms of the relative contribution of additive genetic variance and non-additive genetic variance. Besides the estimation of the components of genetic variation an overall picture about the genetic architecture was obtained by Wr, Vr graphs. The results summarized as follows:

Plant height: Partial dominance is indicated for plant height (Fig. 1) with relative proportion of dominant and recessive genes in the parents. Exotic variety SP 8886 occupies a position nearest to the origin in the graph, indicating an excess of dominant genes. Another exotic variety Coker310 is second in the proportion of dominant genes.

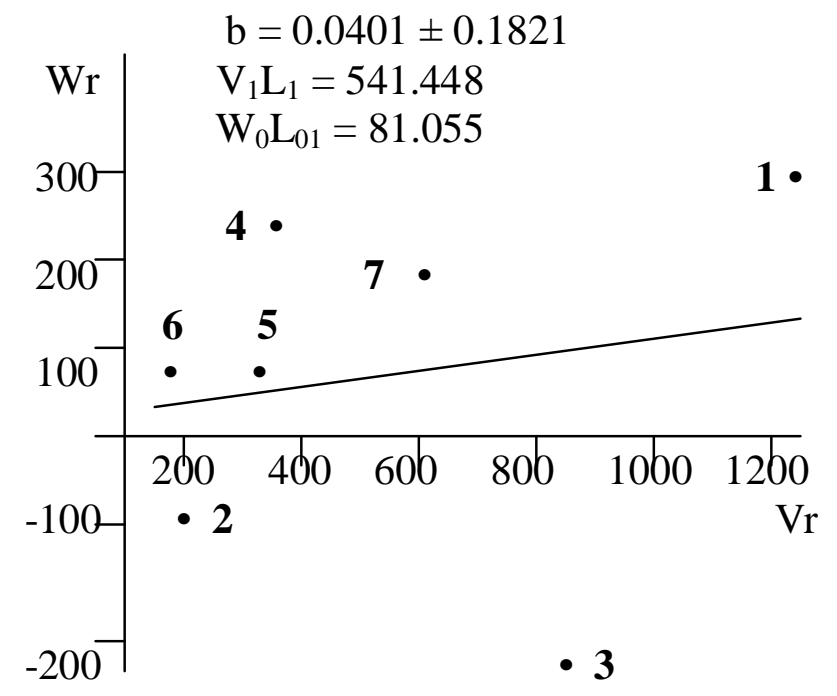

Fig. 1 : Vr/Wr graph for plant height

Halab90 is located farthest from the point of origin indicating relative abundance of recessive genes. The regression coefficient of $\mathrm{Wr}$ on $\mathrm{Vr}$ unit slope was non-significantly below unity $(b=0.0401 \pm 0.1821)$ which indicates the absence of epistatic gene effect in respect of plant height. The estimated genetic components of variation are presented in table 3. Over-dominance type of gene action is confirmed from the higher magnitude of $\mathrm{H}_{1}$ and $\mathrm{H}_{2}$ than additive component (D). The items $\mathrm{H}_{1}, \mathrm{H}_{2}$ and $\mathrm{D}$ are significant. The mean degree of 
Table 3: Genetic parameters for yield and it's components in upland cotton.

\begin{tabular}{|c|c|c|c|c|c|c|}
\hline Parameters & $\begin{array}{c}\text { Plant } \\
\text { Height }\end{array}$ & $\begin{array}{c}\text { No. } \\
\text { Vegetative } \\
\text { Branches }\end{array}$ & $\begin{array}{c}\text { No. } \\
\text { Fruiting } \\
\text { Branches }\end{array}$ & $\begin{array}{c}\text { No. of } \\
\text { Bolls }\end{array}$ & $\begin{array}{c}\text { Boll } \\
\text { Weight }\end{array}$ & $\begin{array}{c}\text { Seed } \\
\text { cotton } \\
\text { Yield }\end{array}$ \\
\hline $\mathrm{D}$ & $\begin{array}{c}254.18 \pm \\
17.36 \\
\end{array}$ & $\begin{array}{c}0.2323 \pm \\
0.0419\end{array}$ & $\begin{array}{c}1.0662 \pm \\
0.2849\end{array}$ & $\begin{array}{c}5.5132 \pm \\
0.6966\end{array}$ & $\begin{array}{c}0.4439 \pm \\
0.0447\end{array}$ & $\begin{array}{c}236.068 \pm \\
78.2496 \\
\end{array}$ \\
\hline $\mathrm{H}_{1}$ & $\begin{array}{c}2062.88 \pm \\
98.237\end{array}$ & $\begin{array}{c}1.6049 \pm \\
0.0717\end{array}$ & $\begin{array}{c}16.5840 \pm \\
2.2222\end{array}$ & $\begin{array}{c}116.994 \pm \\
13.1706\end{array}$ & $\begin{array}{c}0.6628 \pm \\
0.1159\end{array}$ & $\begin{array}{c}3863.56 \pm \\
650.032\end{array}$ \\
\hline $\mathrm{H}_{2}$ & $\begin{array}{c}1705.65 \pm \\
87.259\end{array}$ & $\begin{array}{c}1.3713 \pm \\
0.0433\end{array}$ & $\begin{array}{c}13.2067 \pm \\
1.8356\end{array}$ & $\begin{array}{c}88.3391 \pm \\
10.4836\end{array}$ & $\begin{array}{c}0.5393 \pm \\
0.1174\end{array}$ & $\begin{array}{c}3210.58 \pm \\
504.856\end{array}$ \\
\hline $\mathrm{h}^{2}$ & $\begin{array}{c}3470.31 \pm \\
147.46\end{array}$ & $\begin{array}{c}0.0201 \pm \\
0.0244\end{array}$ & $\begin{array}{c}14.5915 \pm \\
2.6679\end{array}$ & $\begin{array}{c}35.9541 \pm \\
5.0097\end{array}$ & $\begin{array}{c}0.1769 \pm \\
0.1085\end{array}$ & $\begin{array}{c}1990.23 \pm \\
279.616\end{array}$ \\
\hline $\mathrm{F}$ & $\begin{array}{c}195.539 \pm \\
30.791\end{array}$ & $\begin{array}{c}0.2056 \pm \\
0.0713\end{array}$ & $\begin{array}{c}2.4639 \pm \\
0.5065\end{array}$ & $\begin{array}{c}20.5815 \pm \\
2.9210\end{array}$ & $\begin{array}{c}0.4052 \pm \\
0.0587\end{array}$ & $\begin{array}{c}254.815 \pm \\
247.022\end{array}$ \\
\hline $\mathrm{E}$ & 19.944 & 0.0496 & 0.3459 & 1.9630 & 0.1202 & 161.12 \\
\hline \multicolumn{7}{|c|}{ Derived values } \\
\hline$\left(\mathrm{H}_{1} / \mathrm{D}\right)^{1 / 2}$ & 2.849 & 2.6286 & 3.9439 & 4.6419 & 1.2220 & 4.0455 \\
\hline $\mathrm{H}_{2} / 4 \mathrm{H}_{1}$ & 0.207 & 0.2136 & 0.1991 & 0.1888 & 0.2034 & 0.2078 \\
\hline $\mathrm{KD} / \mathrm{KR}$ & 1.312 & 1.4048 & 1.8288 & 2.3801 & 2.1922 & 1.3079 \\
\hline $\mathrm{h}^{2} / \mathrm{H}_{2}$ & 2.038 & 0.0152 & 1.1049 & 0.4070 & 0.3281 & 0.6199 \\
\hline Heritability & 0.3178 & 0.2491 & 0.2134 & 0.2192 & 0.2413 & 0.2476 \\
\hline
\end{tabular}

dominance $\left(\mathrm{H}_{1} / \mathrm{D}\right)^{1 / 2}$ exceeded unity which also indicate over-dominance for plant height expression. The ratio $\mathrm{H}_{2} / 4 \mathrm{H}_{1}=0.207$ was not quite close to 0.25 and thus indicated unequal mean allelic frequencies at all loci influencing the trait. Similar gene frequencies are also supported by farthest values of $\mathrm{H}_{1}$ and $\mathrm{H}_{2}$. The positive value of $\mathrm{F}$ (195.539) and ratio $\left(4 \mathrm{DH}_{1}\right)^{1 / 2}+\mathrm{F} /\left(4 \mathrm{DH}_{1}\right)^{1 / 2}-\mathrm{F}$ or $(\mathrm{KD} / \mathrm{KR})$ reveals that the genes for higher plant height are more frequent in the parents. The positive estimates of $\mathrm{h}^{2} / \mathrm{H}_{2}$ exhibit the trend of dominance toward the better parents. Narrow sense heritability in the present studies is moderate (0.3178) suggesting that the most of the phenotypic variation would be controlled by additive and non additive gene effects.

Number of vegetative branches: The presentation of $\mathrm{Vr}$ and $\mathrm{Wr}$ graph in the Fig. 2 indicates additive gene effects with a low dominance as the regression line intercepts the Wr-axis above the origin. The estimated genetic components of variation for number of vegetative branches are given in table 3 . The variation due to additive and dominance effects is significant from zero indicating that all the components play important role in controlling the character. Mean degree of dominance depicted from the ratio $\left(\mathrm{H}_{1} / \mathrm{D}\right)^{1 / 2}$ exceeded unity which indicate over-dominance for number of vegetative branches expression. The value of $\mathrm{H}_{2} / 4 \mathrm{H}_{1}(=0.2136)$ which is less than 0.25 , suggests unequal gene frequencies i.e. $\mathrm{u} / \mathrm{v}$ at all loci is evident. The positive value of $\mathrm{F}(0.2056)$ and ratio obtained from $\left(4 \mathrm{DH}_{1}\right)^{1 / 2}+\mathrm{F} /\left(4 \mathrm{DH}_{1}\right)^{1 / 2}-\mathrm{F}$ or $(\mathrm{KD} / \mathrm{KR})$ reveals that genes for higher number of vegetative branches are more frequent in the parents. The positive estimates of $h^{2}$ 


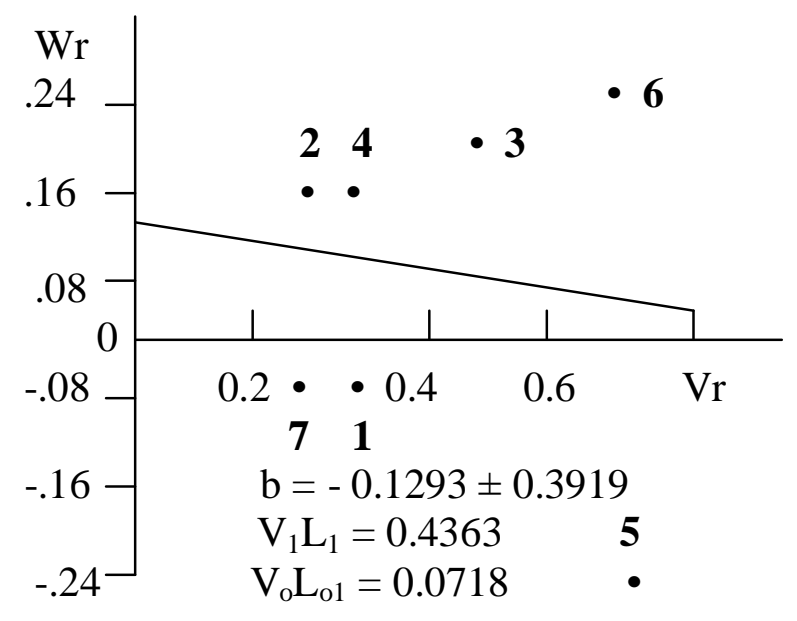

Fig. 2 : Vr/Wr graph for number of vegetative branches

and $\mathrm{h}^{2} / \mathrm{H}_{2}$ show the trend of dominance toward the higher number of vegetative branches. The low heritability (0.2491) signifies the major role of dominance gene effects relative to additive as for the number of vegetative branches was concerned.

Number of fruiting branches: Negative interception of regression line in Fig., 3 and significant and higher magnitude of $\mathrm{H}_{1}$ and $\mathrm{H}_{2}$ than $\mathrm{D}$ (Table 3) are the evidence of over dominance type of gene action for number of fruiting branches, as well as the $\left(\mathrm{H}_{1} / \mathrm{D}\right)^{1 / 2}$ ratio (more than one) considered as another evidence of over-dominance. Mane and Phatade (1992) also reported over-dominance and emphasized that conventional breeding methods, which exploit only additive genetic variation, was not usefull for the genetic improvements in case of number of fruiting branches. The ratio $\mathrm{H}_{2} / 4 \mathrm{H}_{1}=0.1991$ below the maximum value of 0.25 ,

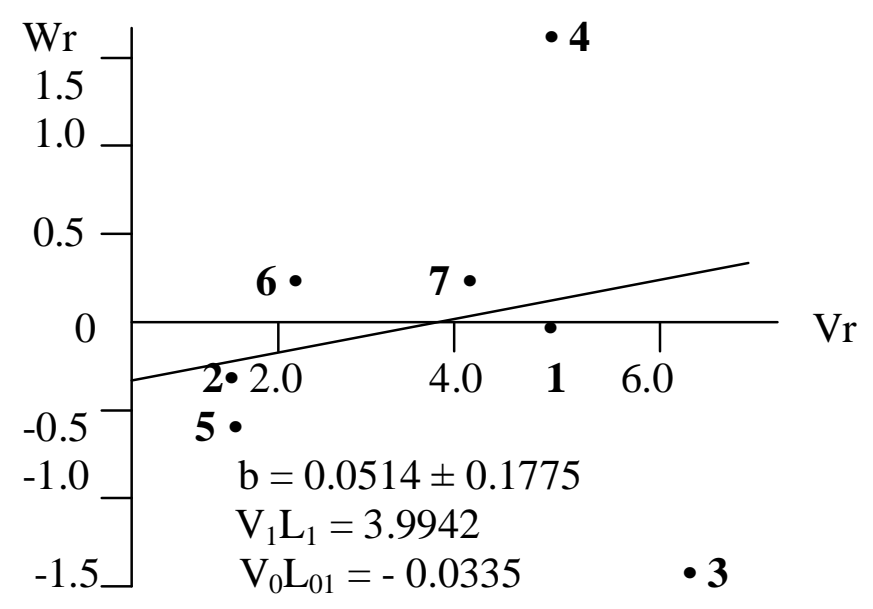

Fig. 3 : Vr/Wr graph for number of fruiting branches

suggesting unequal positive and negative allelic frequencies in parents. Greater than one (1.8288) proportion of: $\left(4 \mathrm{DH}_{1}\right)^{1 / 2}+\mathrm{F}\left(4 \mathrm{DH}_{1}\right)^{1 / 2}-\mathrm{F}$ indicates inequality between the 
number of dominants and recessive alleles in the parents. Varieties SP8886 and Dunn 1047 with low variance covariance values (Table 1, Fig.3) have the excess of dominant genes. Ascending the line, are the parents having increasing proportion of recessive genes. Deltapine5409 and Lachata being farthest away from the graphic origin seem to have a preponderance of recessive genes. The positive estimates of $h^{2}$ and $h^{2} / \mathrm{H}_{2}$ make the trend of dominance toward the higher number of fruiting branches parents. Narrow sense heritability given in table 3 was low (0.2134) proposing non additive variation and higher environmental influence on the phenotypic manifestation of the trait.

Number of bolls per plant: The regression line intercepted the $\mathrm{Wr}$ axis above the origin point (Fig. 4) suggesting partial dominance for this character.

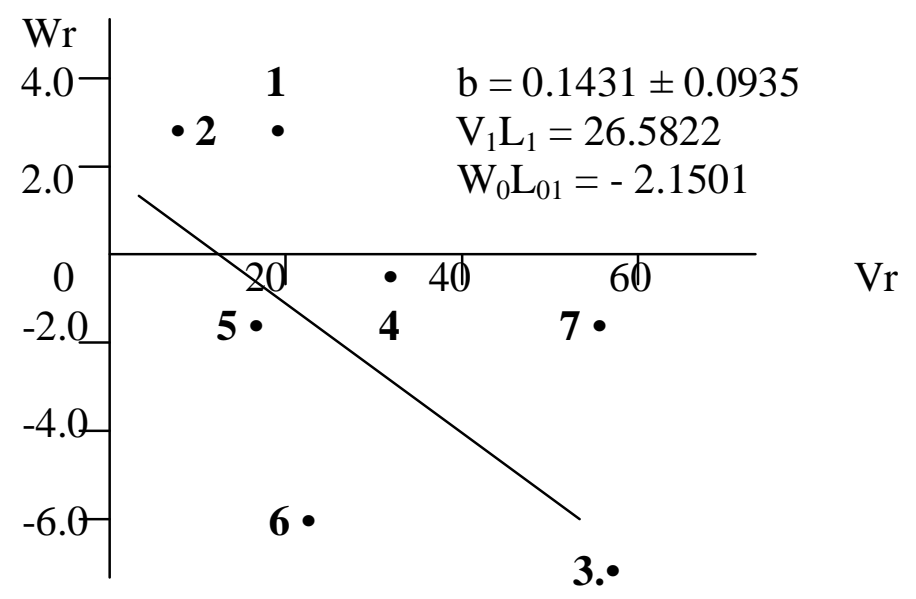

Fig. 4 : Vr/Wr graph for number of bolls/plant

The regression coefficient of $\mathrm{Wr}$ on $\mathrm{Vr}$ was significantly below unity which indicated the presence of interallelic or multiple allelic genetic effect, though of high magnitude. Parents SP8886 and Dunn1047 have the excess of dominant genes, while Deer22 seems to have the maximum concentrations of recessive genes. Significant and higher magnitude of $\mathrm{H}_{1}$ and $\mathrm{H}_{2}$ than $\mathrm{D}$ and more than one $\left(\mathrm{H}_{1} / \mathrm{D}\right)^{1 / 2}$ value (Table 3 ) are the evidence of overdominance type of gene action for this character, and that is similar to the findings of Ahmad et al. (2005). Ratio of $\mathrm{H}_{2} / 4 \mathrm{H}_{1}$ (0.1888) was very far from 0.25 Indicating asymmetrical distribution of the positive and negative allelic frequencies among the parents. high ratio of $\left(4 \mathrm{DH}_{1}\right)^{1 / 2}+\mathrm{F}\left(4 \mathrm{DH}_{1}\right)^{1 / 2}-\mathrm{F}$ suggesting the asymmetry of gene distribution amongst the parents, whereas $\mathrm{h}^{2} / \mathrm{H}_{2}$ ratio $(=0.4070)$ indicating a high proportion of recessive genes for this character, which does not mean that this character was not governed with the dominant genes, as such a situation may arise by negligible effect of positive and negative genes. The low heritability (0.2192) signifies the major role of dominance gene effects relative to additive one for this character.

Boll weight: The regression line intercepted the Wr axis below the origin point suggesting the presence of over-dominance for boll weight (Fig. 5) with relative 


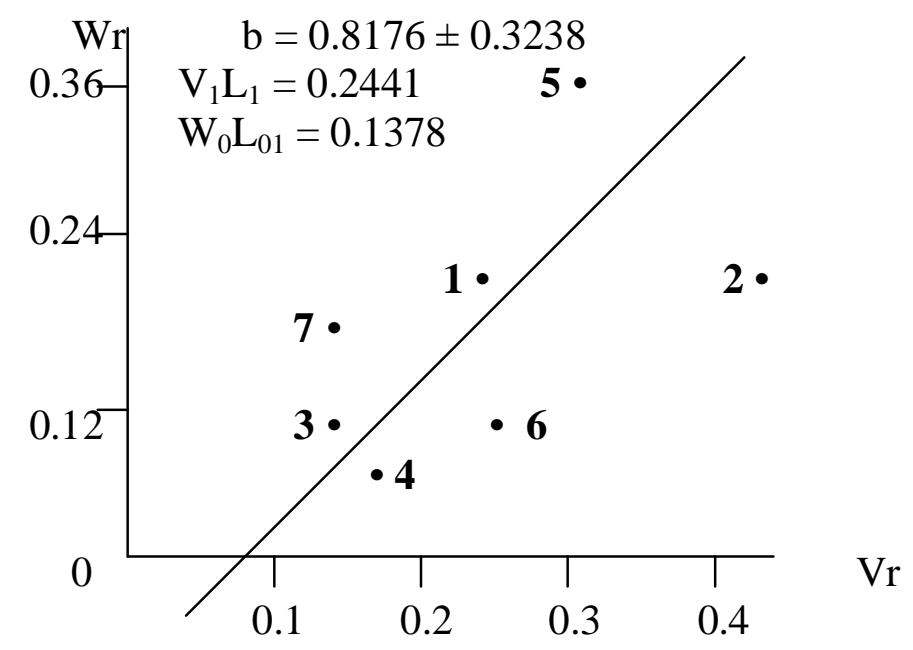

Fig. 5 : Vr/Wr graph for boll weight

proportion of dominant and recessive genes in the parents. The varieties Delta pine5409 and Lachata occupies a position nearest to the origin, and thus had the maximum concentration of dominant genes, while the varieties SP8886 and Dunn1047 had higher concentration of recessive genes, due to its position away from origin point. The significant deviation of regression line from unit slope $(b=0.8176 \pm 0.3238)$ indicated non allelic interaction in the phenotypic manifestation of this trait. From table 3, over-dominance type of gene action was confirmed from the higher magnitudes of $\mathrm{H}_{1}$ and $\mathrm{H}_{2}$ than additive component D. Murtaza (2005) reported non-additive over dominance type of gene action governed the inheritance of boll weight. The three items $\mathrm{H}_{1}, \mathrm{H}_{2}$ and $\mathrm{D}$ were significant. The mean degree of dominance $\left(\mathrm{H}_{1} / \mathrm{D}\right)^{1 / 2}$ exceeds unity which also indicate over-dominance for boll weight expression. The ratio $\mathrm{H}_{2} / 4 \mathrm{H}_{1}=0.2034$, far from 0.25 , thus indicated asymmetry of positive and negative genes distribution governed this character. The positive value of $\mathrm{F}, 0.4052$ and ratio obtained from $\left(4 \mathrm{DH}_{1}\right)^{1 / 2}+\mathrm{F} /\left(4 \mathrm{DH}_{1}\right)^{1 / 2}-\mathrm{F}$ revealed that genes for higher boll weight were more frequent in the parents. The ratio of $\mathrm{h}^{2} / \mathrm{H}_{2}(=0.3281)$ indicating high proportion of recessive genes for this character. Low narrow sense heritability (0.2413) suggesting that most of the phenotypic variation would be non-additive and environmental.

Seed cotton yield: Fig. 6 showed that the regression line cut the $\mathrm{Wr}$ axis above the point of origin suggesting partial dominance for seed cotton yield. The estimated genetic components of variation for seed cotton yield are given in Table 3 . The variation due to additive, dominance and environ mental deviation is significant from zero indicating that all the components played an important role in controlling this character. Mean degree of dominant depicted from the high ratio of $\left(\mathrm{H}_{1} / \mathrm{D}\right)^{1 / 2}$ indicates over- dominance. The low value of $\mathrm{H}_{2} / 4 \mathrm{H}_{1}$, which is 


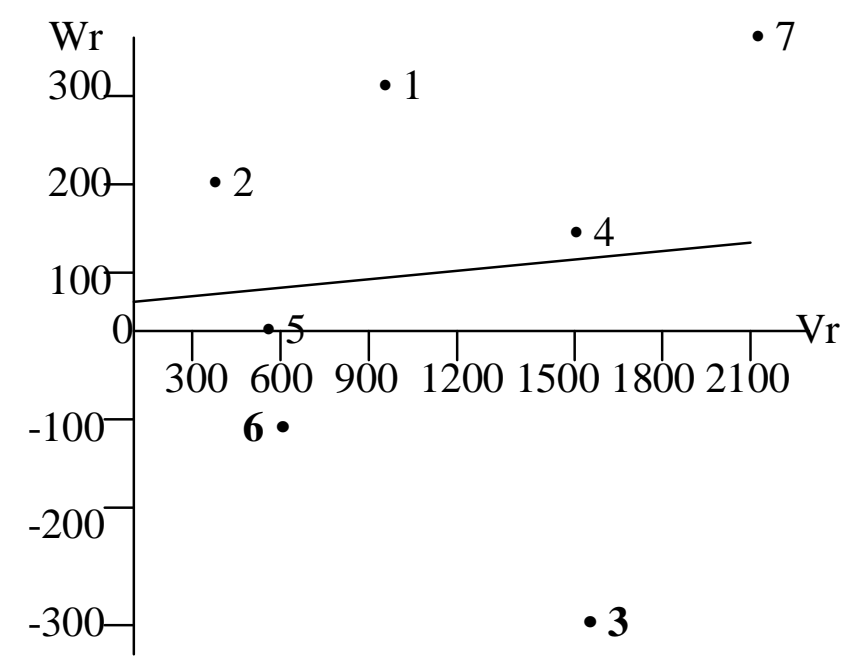

Fig. $6: \mathrm{Vr} / \mathrm{Wr}$ graph for seed cotton yield

less than 0.25, suggested unequal gene frequencies i.e. $\mathrm{u} / \mathrm{v}$ at all loci is evident. The positive and significant $\mathrm{F}$ value indicated an excess of dominants genes with positive effects. The ratio $\left(4 \mathrm{DH}_{1}\right)^{1 / 2}+\mathrm{F} /\left(4 \mathrm{DH}_{1}\right)^{1 / 2}-\mathrm{F}$ was closest to unity for this trait indicating symmetrical distribution of positive and negative genes, while the ratio of $h^{2} / \mathrm{H}_{2}$ was lower than one indicating a higher proportion of recessive genes for this character. Narrow sense heritability (0.2476) suggesting that most of the phenotypic variation would be non-additive and environmental, Ali et al., (2009) reported similar results for this trait.

From the foregoing discussions it is concluded that contributions were made by genes exhibiting some degree of dominance and contribution of different genes depend on the magnitude of their effects. The estimates of gene components suggests the range of dominance, for the studied characters, was from partial to over-dominance. Further more, the role of real gene effects (additive) and their allelic (dominance) and non allelic (epistasis) interactions have been clearly demonstrated in the reported results. Thus, while breeding cotton varieties for seed cotton yield and other related characters, non of these components should be ignored.

\section{REFERENCES}

Ahmad, R. D.; Malic, A. J.; Hassan , G. ; Khan, M. U. (2005). Genetic architecture of some quantitative traits of cotton (Gossypium hirsutum L.). Gomal Univ., J. of Res., 21: 55-57.

Alam, A. K. M.; Roy, N. C.; Islam, H. (1991). Line x Tester analysis of heterosis and combining ability in upland cotton (Gossypium hirsutum L.). Bangladesh J. of Plant Breeding and Genetics, 4(1-2), 27-32.

Ali, M. A.; Abbas, A.; Younas, M.; Khan ,T. M. ; Hassan, H. M. (2009). Genetic basis of some quantitative traits in upland cotton (Gossypium hirsutm L.). Plant Omics J. 2(2), 91-97. 
Gomma, M. A. M., (1997). Genetic studies on yield, yield components and Fiber properties in three Egyptian cotton crosses. Annals of agric. Sci., Cairo. 42(1), 195206.

Gomez, K. A. ; . Gomez, A. A (1983). "Statistical Procedures for Agricultural Research". 2nd edn., John Wiley and Sons, New York.680p.

Green, C. C. ; Culp, T. W. (1990). Simultaneous improvement of yield, fiber quality, and yarn strength in upland cotton. Crop Sci. (USA). 3(1), 66-69.

Hayman, B. I., (1954a). The theory and analysis of diallel crosses. Genetics, 39, 789-809.

Hayman, B. I., (1954b). The analysis of variance of diallel crosses. Biometrics, 10, 235-244.

Jagtab, D. R., (1986). Combining ability in upland cotton. Indian J. of Agric. Sci. (India) 56(12), 833-840.

Jagtab, D. R. ; Kohle, A. K. (1987). Graphical and combining ability analysis in cotton. Indian J. Agric. Sci. (India), 57(12), 456-464.

Jinks, J. L., (1954). The analysis of continuous variation in diallel crosses of Nicotiana rustica cultivars. Genetics, 39(6), 767-788.

Khan, M. A. J.; Khan, M. A. ; Lodhi, T. E. (1999). Genetic study of yield and yield related components in cotton (Gossypium hirsutum L.). J. Animal and Plant Sci. (Pakistan), 9(1-2), 73-75.

Mather, K. ; Jinks, J. L. (1977). "Introduction to Biometrical Genetics", London, Chapman and Hall.231p.

Mather, K.; Jinks, J. L. (1982)."Biometrical Genetics". 3rd edn, London, Chapman and Hall.382p.

Murtaza, N. (2005). Study of gene effects for boll number, boll weight and seed index in cotton. J. of Central European Agric. 6 (3), 255-262.

Radi, M. S.; Hendawi, F. A.; Abdel-Hamid, A. M. ; Ismail, R. M. (1999). Combining ability of yield and yield components in cotton. Egypt. J. Agron., 21, 15-36.

Tariq, M.; Khan ,M. A. ; Idris, G. (1995). Inheritance of boll weight, boll number and yield of seed cotton in upland cotton (Gossypium hirsutum L.). Sarhad J. Agric. Res. (Pakistan), 11(5), 599-605.

Tomar, S. K. ; Singh, S. P. (1992). Combining ability analysis over environment in Asiatic cotton (Gossypium arboreum L.). Indian J. Genet. and Plant Breeding (India), 52(3), 264-269. 